International Journal of Medical Sciences

ISSN 1449-1907 www.medsci.org 2008 5(4):218-223

Research Paper

(C) Ivyspring International Publisher. All rights reserved

\title{
Methods of preventing vinorelbine-induced phlebitis: an experimental study in rabbits
}

\section{Emiko Kohno', Saori Murase², Mayumi Nishikata², Noboru Okamura², Sumio Matzno², Takashi Kuwahara², and Kenji Matsuyama ${ }^{4}$}

1. Department of Hospital Pharmacy, Kansai Medical University Takii Hospital, 10-15 Fumizono-cho, Moriguchi, Osaka 570-8507, Japan

2. Department of Clinical Pharmacy, School of Pharmaceutical Sciences, Mukogawa Women's University, 11-68 Koshien-Kyuban-cho, Nishinomiya, Hyogo 663-8179, Japan

3. Research Fellow, Drug Safety Research Institute, Otsuka Pharmaceutical Factory, Inc., 115 Muya-cho, Naruto Tokushima, 772-8601, Japan

4. Department of Clinical Pharmacy, Faculty of Pharmacy, Keio University, 1-5-30 Shibakoen, Minato-ku, Tokyo 105-8512, Japan

Correspondence to: Emiko Kohno, MS, Vice Director, Department of Pharmacy, Kansai Medical University Takii Hospital, 10-15 Fumizono-cho, Moriguchi, Osaka 570-8507, Japan. Tel: +81-6-6992-1001, Fax: +81-6-6995-5425, E-mail: kohnoe@takii.kmu.ac.jp

Received: 2008.05.09; Accepted: 2008.07.21; Published: 2008.07.22

Purpose: In order to identify methods for preventing phlebitis caused by intravenous administration of vinorelbine (VNR), we established a procedure for estimating the severity of phlebitis in an animal model.

Methods: Four different factors (administration rate, dilution, flushing, and infusion of fat emulsion) were evaluated for alleviation of phlebitis caused by VNR infusion. VNR was diluted with normal saline to prepare test solutions with concentrations of $0.6 \mathrm{mg} / \mathrm{mL}$ or $0.3 \mathrm{mg} / \mathrm{mL}$ for infusion into the auricular veins of rabbits. Two days after VNR infusion, the veins were subjected to histopathological examination.

Results: VNR did not cause obvious loss of venous endothelial cells, the most sensitive and common feature of phlebitis, but VNR infusion led to inflammatory cell infiltration, edema, and epidermal degeneration.

Tissue damage was significantly decreased by shortening the administration time and by diluting the VNR solution for infusion from $0.6 \mathrm{mg} / \mathrm{mL}$ to $0.3 \mathrm{mg} / \mathrm{mL}$. However, there was no effect of flushing with normal saline after VNR infusion, while treatment with fat emulsion before and after VNR infusion only had a minimal effect.

Conclusion: Rapid infusion and dilution are effective methods of reducing phlebitis caused by the infusion of VNR, but the efficacy of flushing with normal saline or infusion of fat emulsion was not confirmed.

Key words: vinorelbine, phlebitis, rabbit ear vein, infusion rate, solution concentration

\section{Introduction}

Vinorelbine (VNR) is a semi-synthetic vinca alkaloid derived from vinblastine that is used to treat non-small cell lung cancer (NSCLC) and breast cancer. For the treatment of NSCLC, VNR is administered at a dose of 20 to $25 \mathrm{mg} / \mathrm{m}^{2}$ alone [1] or in combination with cisplatin [2] or gemcitabine [3,4]. VNR is also administered at a dose of $25 \mathrm{mg} / \mathrm{m}^{2}$ alone or combined with cisplatin or trastuzumab in patients with inoperable, advanced, and recurrent breast cancer, who have previously received anthracyclines and taxanes [5,6]. The main adverse effects of VNR are granulocytopenia, leucopenia, and thrombocytopenia, with granulocytopenia being the primary dose-limiting toxicity. Phlebitis is another problematic adverse effect of intravenous VNR, and the incidence of phlebitis (local venous toxicity) after a 6-min infusion of VNR has been reported as 16-33\% [7-9]. Phlebitis limits the continuation of chemotherapy by decreasing patient motivation and compliance.

VNR has been reported to cause venous discoloration and chemical phlebitis proximal to the site of injection, as well as localized rashes and urticaria, blistering, and skin sloughing [10]. It is a vesicant and venous irritant like other vinca alkaloids. Factors that influence the development of phlebitis include the quality of the vein selected, the size and type of catheter used, the duration of infusion, and the $\mathrm{pH}$ and 
osmolality of the drug solution. The Japanese package insert for VNR recommends dilution with $50 \mathrm{~mL}$ of normal saline or $5 \%$ glucose and administration over less than $10 \mathrm{~min}$, followed by flushing of the vein but the effectiveness of this protocol has not been evaluated.

The purpose of the present study was to establish an experimental method for estimating the severity of phlebitis caused by VNR in rabbits, and then to test various methods that have been reported for preventing phlebitis caused by intravenous VNR, including more rapid administration, dilution, flushing, and infusion of fat emulsion [11-13].

\section{Materials and Methods}

\section{Animals}

Male Japanese white rabbits (Std; JW, Japan SLC, Inc., Shizuoka, Japan) weighing between 2.3 and 3.5 $\mathrm{kg}$ were housed in individual cages in an animal room maintained at $23 \pm 3^{\circ} \mathrm{C}$ and $55 \pm 10 \%$ relative humidity with ventilation 13-16 times/hr and a 12-hr light-dark cycle. The rabbits were allowed free access to diet and water, except during treatment. This study was approved by the Committee on Animal Experiments of Mukogawa Women's University.

\section{Drugs}

Navelbine ${ }^{\circledR}$ Injection (VNR) was kindly provided by Kyowa Hakko Kogyo Co. (Tokyo, Japan). A 1- mL vial of Navelbine ${ }^{\circledR}$ Injection was diluted with normal saline (Otsuka Normal Saline; Otsuka Pharmaceutical Factory, Inc., Tokushima, Japan) to provide either a 0.6 $\mathrm{mg} / \mathrm{mL}$ or $0.3 \mathrm{mg} / \mathrm{mL}$ solution of VNR. In addition, normal saline and $20 \%$ fat emulsion (Intralipos ${ }^{\circledR} 20 \%$ : Otsuka Pharmaceutical Factory, Inc.) were tested to examine their influence on VNR-induced phlebitis.

\section{Experimental procedure}

Test solutions were infused through a plastic catheter (Surflo, 24 gauge, outer diameter of $0.67 \mathrm{~mm}$ and length of $19 \mathrm{~mm}$; Terumo Co., Tokyo, Japan) into an ear vein using a peristaltic pump (Minipuls 2, Gilson, Inc., WI, USA) (Figure 1). Veins in both ears were employed to compare different infusion conditions. The dose of VNR was set at $1.5 \mathrm{mg} / \mathrm{kg}$ in all experiments. Rabbits were killed by an overdose of sodium pentobarbital (Nembutal ${ }^{\circledR}$, Dainippon Sumitomo Pharmaceutical Co., Osaka, Japan) at 2 days after infusion. Two samples of the ear vein were obtained, including the region $3-10 \mathrm{~mm}$ from the catheter tip (proximal region) and the region $20-30 \mathrm{~mm}$ from the catheter tip (distal region) (Figure 1). These were fixed in phosphate-buffered saline containing $10 \%$ formalin. Then cross-sections of the ear vein were prepared and stained with hematoxylin and eosin (HE). Histopathological examination was performed blindly, with the findings being graded according to the criteria shown in Table 1. These criteria were based on those of Kuwahara [14], with the addition of epidermal degeneration.

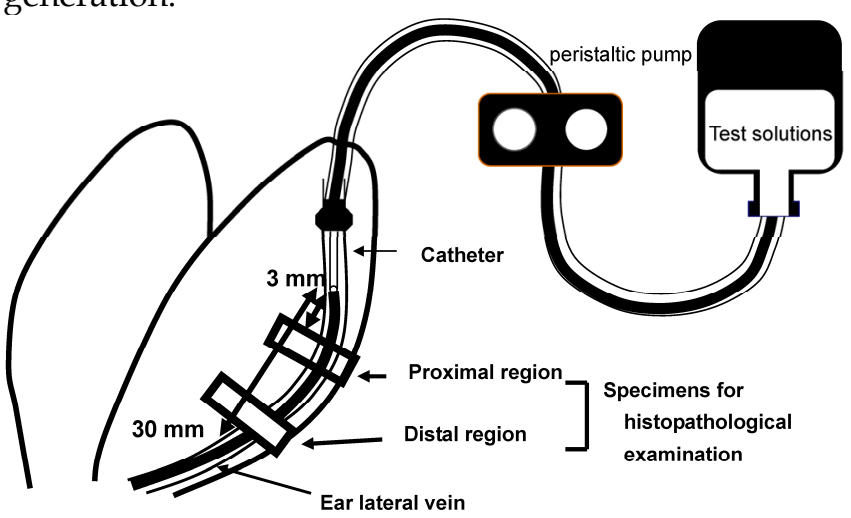

Figure 1. Sites of histopathological examination. Two regions of the ear vein, one located 3-10 $\mathrm{mm}$ from the catheter tip (proximal region) and the other located 20-30 $\mathrm{mm}$ (distal region) from it, were sampled at 2 days after infusion.

Table 1 Criteria for histopathological examination

\begin{tabular}{|c|c|}
\hline Histopathological findings* & Grade \\
\hline \multicolumn{2}{|l|}{ Loss of venous endothelial cells } \\
\hline None & 0 \\
\hline Less than $1 / 3$ of the vein (in cross-section) & 1 \\
\hline $1 / 3$ to $2 / 3$ of the vein & 2 \\
\hline More than $2 / 3$ of the vein & 3 \\
\hline \multicolumn{2}{|l|}{ Inflammatory cell infiltration } \\
\hline None & 0 \\
\hline $\begin{array}{l}\text { Few inflammatory cells in venous wall or perivascu- } \\
\text { lar tissue }\end{array}$ & 1 \\
\hline $\begin{array}{l}\text { Many inflammatory cells in venous wall or perivas- } \\
\text { cular tissue }\end{array}$ & 2 \\
\hline $\begin{array}{l}\text { More diffuse and dense inflammatory cell infiltrates } \\
\text { in perivascular tissue }\end{array}$ & 3 \\
\hline \multicolumn{2}{|l|}{ Edema } \\
\hline None & 0 \\
\hline Localized to perivascular tissue & 1 \\
\hline More diffuse edema & 2 \\
\hline Edema of the entire region & 3 \\
\hline \multicolumn{2}{|l|}{ Epidermal degeneration } \\
\hline None & 0 \\
\hline Some degenerated epidermal cells near the vein & 1 \\
\hline $\begin{array}{l}\text { Numerous degenerated epidermal cells near the vein } \\
\text { (More diffuse and severe epidermal degeneration) }\end{array}$ & 2 \\
\hline
\end{tabular}

*: The sections were stained with hematoxylin and eosin (HE). Histopathological examinations was performed blindly, and the findings were graded.

\section{Influence of the infusion rate}

In 8 rabbits, a $0.6 \mathrm{mg} / \mathrm{mL}$ solution of VNR was infused into one ear vein for $30 \mathrm{~min}$ at $5 \mathrm{~mL} / \mathrm{kg} / \mathrm{hr}$ as a control, and the same solution was infused into the contralateral ear vein for $10 \mathrm{~min}$ at $15 \mathrm{~mL} / \mathrm{kg} / \mathrm{hr}$ (3-fold faster). The concentration of VNR was selected to be similar to the clinical concentration range. Before 
and after VNR infusion, normal saline was infused into both veins for $24 \mathrm{~min}$ at $5 \mathrm{~mL} / \mathrm{kg} / \mathrm{hr}$.

\section{Influence of the concentration}

In 8 rabbits, a $0.6 \mathrm{mg} / \mathrm{mL}$ solution of VNR was infused into one ear vein for $30 \mathrm{~min}$ at $5 \mathrm{~mL} / \mathrm{kg} / \mathrm{hr}$ as a control, and a $0.3 \mathrm{mg} / \mathrm{mL}$ solution of VNR was infused into the contralateral ear vein for $30 \mathrm{~min}$ at 10 $\mathrm{mL} / \mathrm{kg} / \mathrm{hr}$.

\section{Effect of flushing with normal saline}

A $0.6 \mathrm{mg} / \mathrm{mL}$ solution of VNR was infused for 30 $\min$ at $5 \mathrm{~mL} / \mathrm{kg} / \mathrm{hr}$ into the right and left ear veins of 8 rabbits. In one ear vein, infusion of VNR was followed by flushing with $5 \mathrm{~mL}$ of normal saline for 1 min, while the other ear vein was not flushed as a control.

\section{Effect of $20 \%$ fat emulsion}

A $0.6 \mathrm{mg} / \mathrm{mL}$ solution of VNR was infused for 30 $\min$ at $5 \mathrm{~mL} / \mathrm{kg} / \mathrm{hr}$ into the right and left ear veins of 8 rabbits. In one ear vein, 20\% fat emulsion (Intralipos $^{\circledR}$ ) was infused for $24 \mathrm{~min}$ at $5 \mathrm{~mL} / \mathrm{kg} / \mathrm{hr}$ both before and after VNR infusion. In the other ear vein, normal saline was infused in the same manner as a control.

\section{Statistical analysis}

The grade of each histopathological finding was compared between groups by the Wilcoxon rank sum test and $p<0.05$ was considered to indicate a significant difference.

\section{Results}

\section{Influence of the infusion rate}

Figure 2 shows a representative photomicrograph of a normal vein without exposure to VNR and Table 2 summarizes the histopathological findings after infusion of VNR at a normal or rapid rate. Infusion of a $0.6 \mathrm{mg} / \mathrm{mL}$ solution of VNR for $30 \mathrm{~min}$ at 5 $\mathrm{mL} / \mathrm{kg} / \mathrm{hr}$ (control) only caused slight loss of venous endothelial cells (Grade 1) in the distal region of the vein in 1 of 8 animals. In addition, there was inflammatory cell infiltration (Grades 2-3) in the proximal and distal regions of the vein in 5 animals each, edema (Grades 1-2) of the proximal vein region in 3 animals and the distal region in 5 animals, and epidermal degeneration (Grades 1-3) at both the proximal and distal regions in all 8 animals (Figure 3). After infusion of the same solution 3 times more rapidly $(10 \mathrm{~min}, 15$ $\mathrm{mL} / \mathrm{kg} / \mathrm{hr}$ ), there was inflammatory cell infiltration (Grades 1-2) at the proximal vein region in 4 out of 8 animals and at the distal region in 3 animals, but edema (Grade 2) was only found in the proximal region of 1 animal. Epidermal degeneration (Grades 1-3) still occurred at both the proximal and distal regions in 7 out of 8 animals. Edema of the distal region was significantly less severe in the rapid infusion group compared with the control infusion group $(p<0.05)$.

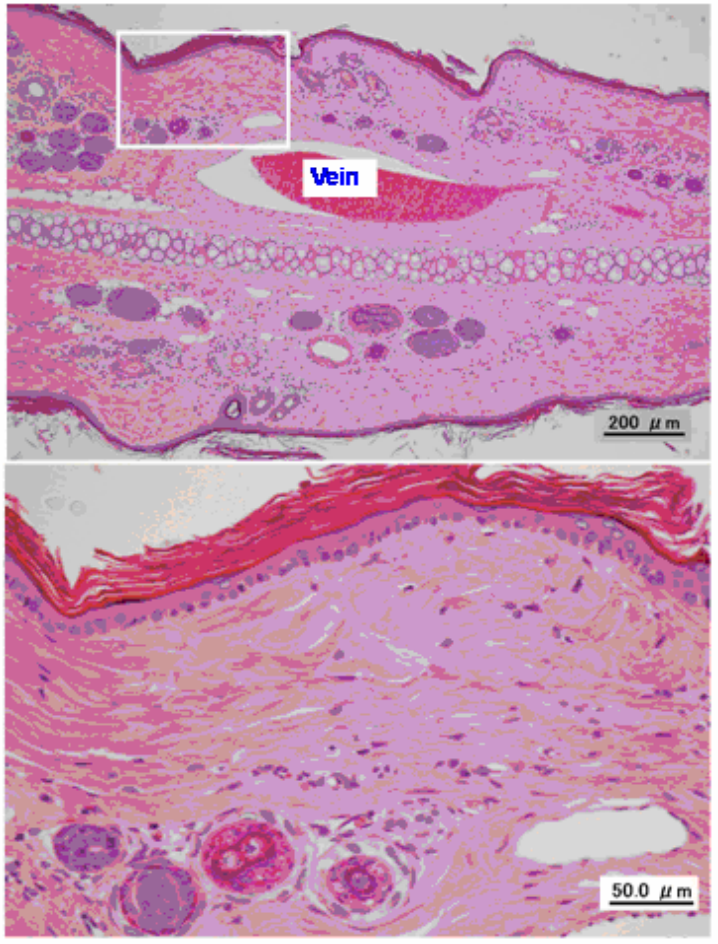

Figure 2. Typical photomicrographs of an untreated ear vein.

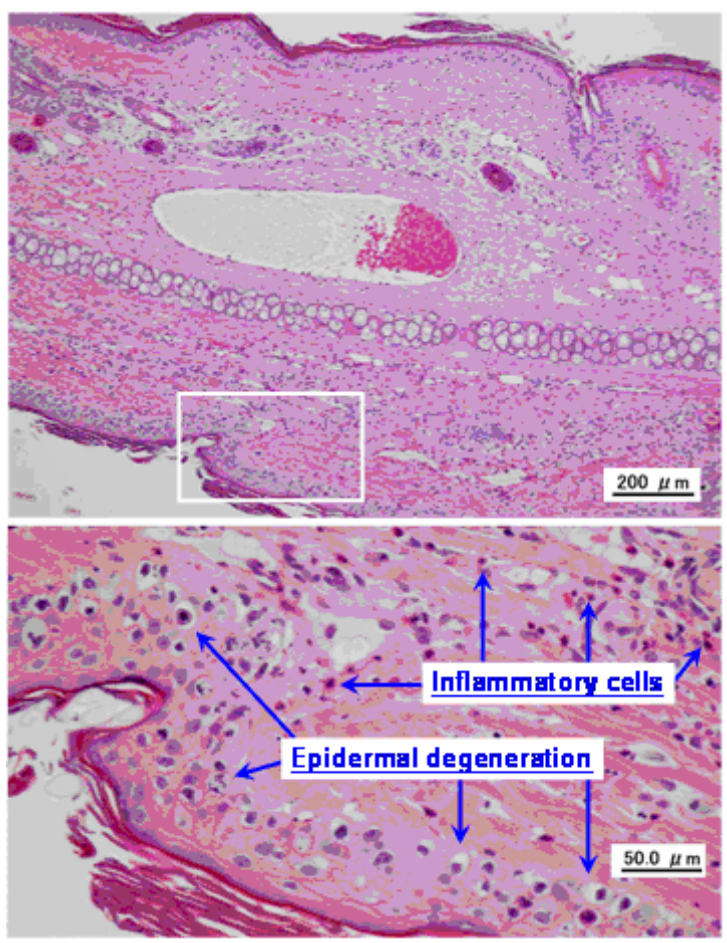

Figure 3. Typical photomicrographs of an ear vein after VNR infusion. A $0.6-\mathrm{mg} / \mathrm{mL}$ solution of VNR was infused into an ear vein for $30 \mathrm{~min}$ at $5 \mathrm{~mL} / \mathrm{kg} / \mathrm{hr}$, and the vein was subjected to pathological examination after 2 days. 
Table 2 Influence of the infusion rate on histopathological changes at 2 days after VNR infusion. In 8 rabbits, a $0.6-\mathrm{mg} / \mathrm{mL}$ solution of VNR was infused into one ear vein for $30 \mathrm{~min}$ at $5 \mathrm{~mL} / \mathrm{kg} / \mathrm{hr}$ as a control, and the same solution was also infused into the contralateral ear vein for $10 \mathrm{~min}$ at $15 \mathrm{~mL} / \mathrm{kg} / \mathrm{hr}$ (3-fold faster).

\begin{tabular}{|c|c|c|c|c|c|c|c|c|c|c|c|c|c|c|c|c|c|c|c|c|c|}
\hline \multirow[t]{2}{*}{ Region } & \multirow{2}{*}{$\begin{array}{l}\text { Infusion rate } \\
\text { Grade }\end{array}$} & \multicolumn{4}{|c|}{$\begin{array}{l}\text { Loss of venous } \\
\text { endothelial cells }\end{array}$} & \multirow[t]{2}{*}{$\begin{array}{l}\mathrm{p} \\
\text { value }\end{array}$} & \multicolumn{4}{|c|}{$\begin{array}{l}\text { Inflammatory } \\
\text { cell infiltration }\end{array}$} & \multirow[t]{2}{*}{$\begin{array}{l}\mathrm{p} \\
\text { value }\end{array}$} & \multicolumn{4}{|c|}{ Edema } & \multirow[t]{2}{*}{$\mathrm{p}$ value } & \multicolumn{4}{|c|}{$\begin{array}{l}\text { Epidermal de- } \\
\text { generation }\end{array}$} & \multirow[t]{2}{*}{$\begin{array}{l}\mathrm{p} \\
\text { value }\end{array}$} \\
\hline & & 0 & 1 & 2 & 3 & & 0 & 1 & 2 & 3 & & 0 & 1 & 2 & 3 & & 0 & 1 & 2 & 3 & \\
\hline \multirow[t]{2}{*}{ Proximal } & Control & 8 & 0 & 0 & 0 & \multirow[t]{2}{*}{ N.S. } & 3 & 0 & 2 & 3 & \multirow[t]{2}{*}{ N.S. } & 5 & 2 & 1 & 0 & \multirow[t]{2}{*}{ N.S. } & 0 & 2 & 3 & 3 & \multirow[t]{2}{*}{ N.S. } \\
\hline & Rapid & 8 & 0 & 0 & 0 & & 4 & 3 & 1 & 0 & & 7 & 0 & 1 & 0 & & 1 & 2 & 4 & 1 & \\
\hline \multirow[t]{2}{*}{ Distal } & Control & 7 & 1 & 0 & 0 & \multirow[t]{2}{*}{ N.S. } & 3 & 0 & 3 & 2 & \multirow[t]{2}{*}{ N.S. } & 3 & 3 & 2 & 0 & \multirow[t]{2}{*}{$<0.05$} & 0 & 3 & 2 & 3 & \multirow[t]{2}{*}{ N.S. } \\
\hline & Rapid & 8 & 0 & 0 & 0 & & 5 & 1 & 2 & 0 & & 8 & 0 & 0 & 0 & & 1 & 3 & 4 & 0 & \\
\hline
\end{tabular}

Numbers in the table represent the number of observations. N.S.; not significant

\section{Influence of the concentration}

The results of histopathological examination are shown in Table 3. Infusion of a $0.6 \mathrm{mg} / \mathrm{mL}$ solution of VNR (control solution) caused slight loss of venous endothelial cells (Grade 1) at the proximal vein region in 2 out of 8 animals and at the distal region in 3 animals, as well as inflammatory cell infiltration (Grades 1-2) in the proximal region of all 8 animals and the distal region of 7 animals. In addition, edema (Grades 1-3) was noted at the proximal region in 4 animals and at the distal region in 5 animals, while epidermal degeneration (Grades 2-3) was seen at both the proximal and distal regions in all 8 animals. The $0.3 \mathrm{mg} / \mathrm{mL}$ solution of VNR (diluted solution) caused slight loss of venous endothelial cells (Grade 1) at the proximal vein region in 3 out of 8 animals and at the distal region in 2 animals, inflammatory cell infiltration (Grades 1-3) in the proximal and distal regions of 6 animals, edema (Grade 2) at the proximal region in 1 animal and the distal region in 3 animals, and epidermal degeneration (Grades 1-3) at both the proximal and distal regions in all 8 animals. Significantly less severe epidermal degeneration at the proximal region was noted after infusion of the diluted solution $(\mathrm{p}<0.05)$.

\section{Effect of flushing with normal saline}

Table 4 shows a comparison of the histopathological grades between VNR infusion with and without a normal saline flush. Flushing with normal saline led to a slight reduction in the loss of venous endothelial cells, but the improvement was not statistically significant.

\section{Effect of $20 \%$ fat emulsion}

The results of histopathological examinations are shown in Table 5. No significant differences were observed after infusion of fat emulsion.

Table 3 Influence of the concentration on histopathological changes at 2 days after VNR infusion. In 8 rabbits, a $0.6-\mathrm{mg} / \mathrm{mL}$ solution of VNR was infused into one ear vein for $30 \mathrm{~min}$ at $5 \mathrm{~mL} / \mathrm{kg} / \mathrm{hr}$ as a control, and a $0.3-\mathrm{mg} / \mathrm{mL}$ solution of VNR was infused into the contralateral ear vein for $30 \mathrm{~min}$ at $10 \mathrm{~mL} / \mathrm{kg} / \mathrm{hr}$.

\begin{tabular}{|c|c|c|c|c|c|c|c|c|c|c|c|c|c|c|c|c|c|c|c|c|c|}
\hline \multirow[t]{2}{*}{ Region } & \multirow{2}{*}{$\begin{array}{l}\text { Solution concentration } \\
\text { Grade }\end{array}$} & \multicolumn{4}{|c|}{$\begin{array}{l}\text { Loss of venous } \\
\text { endothelial cells }\end{array}$} & \multirow[t]{2}{*}{$\begin{array}{l}p \\
\text { value }\end{array}$} & \multicolumn{4}{|c|}{$\begin{array}{l}\text { Inflammatory } \\
\text { cell infiltration }\end{array}$} & \multirow[t]{2}{*}{$\begin{array}{l}\mathrm{p} \\
\text { value }\end{array}$} & \multicolumn{4}{|c|}{ Edema } & \multirow[t]{2}{*}{$\begin{array}{l}p \\
\text { value }\end{array}$} & \multicolumn{4}{|c|}{$\begin{array}{l}\text { Epidermal de- } \\
\text { generation }\end{array}$} & \multirow[t]{2}{*}{ p value } \\
\hline & & 0 & 1 & 2 & 3 & & 0 & 1 & 2 & 3 & & 0 & 1 & 2 & 3 & & 0 & 1 & 2 & 3 & \\
\hline \multirow[t]{2}{*}{ Proximal } & Control & 6 & 2 & 0 & 0 & N.S. & 0 & 2 & 6 & 0 & \multirow[t]{2}{*}{ N.S. } & 4 & 2 & 2 & 0 & \multirow[t]{2}{*}{ N.S. } & 0 & 0 & 5 & 3 & \multirow[t]{2}{*}{$<0.05$} \\
\hline & Dilution & 5 & 3 & 0 & 0 & & 2 & 3 & 3 & 0 & & 7 & 0 & 1 & 0 & & 0 & 2 & 6 & 0 & \\
\hline \multirow[t]{2}{*}{ Distal } & Control & 5 & 3 & 0 & 0 & N.S. & 1 & 1 & 6 & 0 & \multirow[t]{2}{*}{ N.S. } & 3 & 1 & 3 & 1 & \multirow[t]{2}{*}{ N.S. } & 0 & 0 & 5 & 3 & \multirow[t]{2}{*}{ N.S. } \\
\hline & Dilution & 6 & 2 & 0 & 0 & & 2 & 3 & 2 & 1 & & 5 & 0 & 3 & 0 & & 0 & 2 & 5 & 1 & \\
\hline
\end{tabular}

Numbers in the table represent the number of observations. N.S.; not significant

Table 4 Effect of flushing with normal saline on histopathological changes at 2 days after VNR infusion. A $0.6-\mathrm{mg} / \mathrm{mL}$ solution of VNR was infused for $30 \mathrm{~min}$ at $5 \mathrm{~mL} / \mathrm{kg} / \mathrm{hr}$ into the right and left ear veins of 8 rabbits. In one ear vein, VNR infusion was followed by flushing with normal saline $(5 \mathrm{~mL}$ over $1 \mathrm{~min})$, while the other ear vein was not flushed as a control.

\begin{tabular}{|c|c|c|c|c|c|c|c|c|c|c|c|c|c|c|c|c|c|c|c|c|c|}
\hline \multirow[t]{2}{*}{ Region } & \multirow{2}{*}{$\begin{array}{l}\text { Saline flush } \\
\text { Grade }\end{array}$} & \multicolumn{4}{|c|}{$\begin{array}{l}\text { Loss of venous } \\
\text { endothelial cells }\end{array}$} & \multirow[t]{2}{*}{$\begin{array}{l}p \\
\text { value }\end{array}$} & \multicolumn{4}{|c|}{$\begin{array}{l}\text { Inflammatory } \\
\text { cell infiltration }\end{array}$} & \multirow[t]{2}{*}{$\begin{array}{l}p \\
\text { value }\end{array}$} & \multicolumn{4}{|c|}{ Edema } & \multirow[t]{2}{*}{$\begin{array}{l}p \\
\text { value }\end{array}$} & \multicolumn{4}{|c|}{$\begin{array}{l}\text { Epidermal de- } \\
\text { generation }\end{array}$} & \multirow[t]{2}{*}{$\begin{array}{l}p \\
\text { value }\end{array}$} \\
\hline & & 0 & 1 & 2 & 3 & & 0 & 1 & 2 & 3 & & 0 & 1 & 2 & 3 & & 0 & 1 & 2 & 3 & \\
\hline \multirow[t]{2}{*}{ Proximal } & Without flush & 4 & 4 & 0 & 0 & \multirow[t]{2}{*}{ N.S. } & 1 & 3 & 4 & 0 & \multirow[t]{2}{*}{ N.S. } & 1 & 6 & 1 & 0 & \multirow[t]{2}{*}{ N.S. } & 0 & 0 & 4 & 4 & \multirow[t]{2}{*}{ N.S. } \\
\hline & With flush & 7 & 1 & 0 & 0 & & 1 & 0 & 5 & 2 & & 3 & 1 & 3 & 1 & & 0 & 0 & 4 & 4 & \\
\hline \multirow[t]{2}{*}{ Distal } & Without flush & 6 & 2 & 0 & 0 & \multirow[t]{2}{*}{ N.S. } & 1 & 1 & 6 & 0 & \multirow[t]{2}{*}{ N.S. } & 2 & 2 & 4 & 0 & \multirow[t]{2}{*}{ N.S. } & 0 & 0 & 6 & 2 & \multirow[t]{2}{*}{ N.S. } \\
\hline & With flush & 7 & 1 & 0 & 0 & & 2 & 1 & 4 & 1 & & 3 & 1 & 3 & 1 & & 0 & 1 & 4 & 3 & \\
\hline
\end{tabular}

Numbers in the table represent the number of observations. N.S.; not significant 
Table 5 Effect of fat emulsion on histopathological changes at 2 days after VNR infusion. A 0.6-mg/mL solution of VNR was infused for $30 \mathrm{~min}$ at $5 \mathrm{~mL} / \mathrm{kg} / \mathrm{hr}$ into the right and left ear veins of 8 rabbits. In one ear vein, 20\% fat emulsion (Intralipos ${ }^{\mathbb{B}}$ ) was infused for $24 \mathrm{~min}$ at $5 \mathrm{~mL} / \mathrm{kg} / \mathrm{hr}$ before and after VNR infusion. In the other ear vein, normal saline was infused in the same manner as a control.

\begin{tabular}{|c|c|c|c|c|c|c|c|c|c|c|c|c|c|c|c|c|c|c|c|c|c|}
\hline \multirow[t]{2}{*}{ Region } & \multirow{2}{*}{$\begin{array}{l}\text { Fat emulsion treatment } \\
\text { Grade }\end{array}$} & \multicolumn{4}{|c|}{$\begin{array}{l}\text { Loss of venous } \\
\text { endothelial cells }\end{array}$} & \multirow[t]{2}{*}{$\begin{array}{l}p \\
\text { value }\end{array}$} & \multicolumn{4}{|c|}{$\begin{array}{l}\text { Inflammatory } \\
\text { cell infiltration }\end{array}$} & \multirow[t]{2}{*}{$\begin{array}{l}p \\
\text { value }\end{array}$} & \multicolumn{4}{|c|}{ Edema } & \multirow[t]{2}{*}{$\begin{array}{l}\mathrm{p} \\
\text { value }\end{array}$} & \multicolumn{4}{|c|}{$\begin{array}{l}\text { Epidermal de- } \\
\text { generation }\end{array}$} & \multirow[t]{2}{*}{$\begin{array}{l}\mathrm{p} \\
\text { value }\end{array}$} \\
\hline & & 0 & 1 & 2 & 3 & & 0 & 1 & 2 & 3 & & 0 & 1 & 2 & 3 & & 0 & 1 & 2 & 3 & \\
\hline \multirow[t]{2}{*}{ Proximal } & Without treatment & 8 & 0 & 0 & 0 & \multirow[t]{2}{*}{ N.S. } & 2 & 0 & 4 & 2 & \multirow[t]{2}{*}{ N.S. } & 4 & 3 & 1 & 0 & \multirow[t]{2}{*}{ N.S. } & 0 & 0 & 7 & 1 & \multirow[t]{2}{*}{ N.S. } \\
\hline & With treatment & 8 & 0 & 0 & 0 & & 1 & 4 & 3 & 0 & & 4 & 3 & 1 & 0 & & 0 & 2 & 4 & 2 & \\
\hline \multirow[t]{2}{*}{ Distal } & Without treatment & 8 & 0 & 0 & 0 & \multirow[t]{2}{*}{ N.S. } & 1 & 3 & 3 & 1 & \multirow[t]{2}{*}{ N.S. } & 4 & 2 & 2 & 0 & \multirow[t]{2}{*}{ N.S. } & 0 & 1 & 6 & 1 & \multirow[t]{2}{*}{ N.S. } \\
\hline & With treatment & 8 & 0 & 0 & 0 & & 2 & 3 & 3 & 0 & & 3 & 4 & 1 & 0 & & 0 & 3 & 5 & 0 & \\
\hline
\end{tabular}

Numbers in the table represent the number of observations. N.S.; not significant

\section{Discussion}

VNR is widely used to treat solid tumors such as NSCLC [1-4] and breast cancer [5, 6]. Phlebitis due to infusion of VNR is the one of the complications that limits treatment. Various methods of avoiding such phlebitis have been reported [11-13], but none are completely effective. It was reported that rapid infusion and flushing are effective for reducing phlebitis in the clinical setting [7], so an infusion rate of less than 5 minutes [15] but more than 1 minute has been recommended for VNR [7]. To clarify the most efficient methods of preventing VNR induced phlebitis, we evaluated the effects of the VNR infusion rate, VNR concentration, saline flushing, and infusion of fat emulsion on phlebitis in a rabbit auricular vein model.

There is little histopathological information about the effects of VNR infusion in animals and humans. However, infusion into the auricular vein in rabbits has been often used to investigate phlebitis [16-18]. In addition, we have already investigated the influence of osmolarity on phlebitis in this model [19], and the results were consistent with clinical data reported by Kerin and colleagues [20]. Thus, it was thought that this model could be used to investigate phlebitis caused by the infusion of VNR.

Infusion of VNR did not cause marked loss of venous endothelial cells, which is considered to be the most sensitive and common feature of phlebitis due to experimental infusion [16], but it caused epidermal degeneration in almost all cases (Table 3). These findings suggested that VNR has different characteristics from common chemical irritants that induce phlebitis. Although the reason for this difference is unclear, it seems likely that part of a dose of VNR infused into a peripheral vein escapes into the perivascular tissue and reaches the epidermis, where it causes the changes of "epidermal degeneration."

It has been reported that infusion of VNR over 6-10 minutes decreases the incidence of phlebitis compared with infusion over 20-30 minutes [9], and the frequency of phlebitis is even lower decreased with bolus administration over 1 min followed by flushing with normal saline [7]. We also found that tissue damage was decreased by a shorter infusion time, suggesting that this rabbit model was appropriate to investigate VNR-related phlebitis. We confirmed that the infusion rate had an important influence on VNR-induced phlebitis.

It has been suggested that dilution is effective for reducing phlebitis caused by various agents in humans and animals [21, 22]. In this study, we confirmed that dilution could alleviate VNR-induced phlebitis, suggesting that the drug concentration could one of the important factors provoking its occurrence. Thus, it is probably better to dilute VNR before infusion. Flushing with normal saline after VNR infusion and infusion of fat emulsion both before and after VNR were also investigated in this study. Although flushing with normal saline led to a slight reduction in the loss of venous endothelial cells (Table 4), the effect was not significant. The manufacturer of VNR recommends flushing with $>75-125 \mathrm{~mL}$ of fluid after infusion [23], but there is little information about the efficacy of flushing. We did not confirm its usefulness in this study, so further investigation is needed.

Matsusune et al. reported that infusion of fat emulsion reduced phlebitis in patients receiving peripheral parenteral nutrition, and suggested that it had a protective effect on the peripheral veins [24]. However, we did not observe any effect of fat emulsion on phlebitis caused by VNR, suggesting that its infusion might provide insufficient protection.

Phlebitis is considered to be associated with the mechanism of action of VNR. Rapid infusion and dilution with normal saline were both effective for reducing phlebitis after VNR infusion. That is, the development of phlebitis was related to the amount of contact (infusion duration and solution concentration) between VNR and the vascular endothelium. Since greater blood flow allows a more rapid rate of administration and more dilution VNR, choosing a large vessel with rapid blood flow may also be effective for preventing phlebitis caused by VNR infusion. 
In conclusion, our results suggest that rapid administration and dilution of the infusion solution are effective methods for preventing VNR-induced phlebitis. Choosing a large vein might also have a preventive effect, but further studies are needed for confirmation.

\section{Conflict of Interest}

The authors declare that no conflicts of interest exist.

\section{References}

1. Gridelli S. The ELVIS trial: a phase III study of single-agent vinorelbine as first-line treatment in elderly patients with advanced non-small cell lung cancer. Elderly Lung Cancer Vinorelbine Italian Study. Oncologist. 2001; 6:4-7.

2. Kelly K, Crowley J, Bunn PA Jr, et al. Randomized phase III trial of paclitaxel plus carboplatin versus vinorelbine plus cisplatin in the treatment of patients with advanced non-small-cell lung cancer: a Southwest Oncology Group trial. J Clin Oncol. 2001; 19:3210-3218.

3. Gridelli C, Perrone F, Gallo C, et al. Chemotherapy for elderly patients with advanced non-small-cell lung cancer: the Multicenter Italian Lung Cancer in the Elderly Study (MILES) phase III randomized trial. J Natl Cancer Inst. 2003; 95: 362-372.

4. Juergens R, Brahmer J, Ettinger D. Gemcitabine and vinorelbine in recurrent advanced non-small cell lung cancer: sequence does matter. Cancer Chemother Pharmacol. 2007; 59: 621-629.

5. Zelek L, Barthier S, Riofrio M, et al. Weekly vinorelbine is an effective palliative regimen after failure with anthracyclines and taxanes in metastatic breast carcinoma. Cancer. 2001; 92: 2267-2272.

6. Toi M, Saeki T, Aogi K, et al. Late phase II clinical study of vinorelbine monotherapy in advanced or recurrent breast cancer previously treated with anthracyclines and taxanes. Jpn J Clin Oncol. 2005; 35: 310-315.

7. Yoh K, Niho S, Goto K, et al. Randomized trial of drip infusion versus bolus injection of vinorelbine for the control of local venous toxicity. Lung Cancer. 2007; 55: 337-341.

8. Rittenberg CN, Gralla RJ, Rehmeyer TA. Assessing and managing venous irritation associated with vinorelbine tartrate (Navelbine). Oncol Nurs Forum. 1995; 22: 707-710.

9. Nakayama S, Matsubara N, Sakai T, et al. The incidence of phlebitis in patients administered vinorelbine by intravenous bolus injection--a retrospective study. Gan To Kagaku Ryoho. 2002; 29: 633-635.

10. Spratto GR and Woods AL. Vinorelbine tartrate. In: Spratto GR and Woods AL, eds. 2008 EDITION PDR Nurse's Drug Handbook. New York: Thomson Delmar Learning. 2007: 1667-1670.

11. Tononi A, Panzini I, Oliverio G, et al. Vinorelbine chemotherapy in non small cell lung cancer: experience in elderly patients. J Chemother. 1997; 9: 304-308.

12. Weiß J, Wellens WW. The addition of human albumin to vinorelbine solution prevents venous irritation. Onkologie. 1999; 2:416-418.

13. Vassilomanolakis M, Koumakis G, Barbounis V, et al. Prevention of vinorelbine phlebitis with cimetidine. A two-step design study. Support Care Cancer. 2001; 9: 108-111.

14. Kuwahara T, Asanami S, Tamura T, et al. Experimental infusion phlebitis: tolerance $\mathrm{pH}$ of peripheral vein. J Toxicol Sci. 1998; 23: 77-85.

15. Suga $Y$, Hara $Y$, Hashimoto $H$, et al. Consideration of preventive free-flowing IV infusion method for vinorelbine. Gan To Kagaku Ryoho. 2007; 34: 1255-1257.
16. Fonkalsrud EW, Murphy J, Smith FG. Effect of pH in glucose infusions on development of thrombusphlebitis. J Surg Res. 1968; 8: 539.

17. Horviz A, Sacher LA, Elman R. An experimental study of phlebitis following venoclysis with glucose and amino acid solutions. J Lab Clin Med. 1943; 28: 221.

18. Hessov I. Prevention of infusion thrombophlebitis. Acta Anaesthesiol Scand. 1985; 29:33.

19. Kuwahara T, Asanami S, Kubo S. Experimental infusion phlebitis: tolerance osmolality of peripheral venous endothelial cells. Nutrition. 1998; 14: 496-501.

20. Kerin MJ, Pickford IR, Jaeger H, Couse NF, Mitchell CJ, Macfie J. A prospective and randomized study comparing the incidence of infusion phlebitis during continuous and cyclic peripheral parenteral nutrition: effect of a standardized compounded mixture on infusion phlebitis.Br J Surg, 1991; 10: 315.

21. Harrigan CA. A cost-effective guide for the prevention of chemical phlebitis caused by the $\mathrm{pH}$ of the pharmaceutical agent. NITA. 1984; 7: 478-482.

22. Kuwahara T, Asanami S, Tamura T, Kubo S. Dilution is effective in reducing infusion phlebitis in peripheral parenteral nutrition: an experimental study in rabbits. Nutrition. 1998; 14: 186-190.

23. de Lemos ML. Vinorelbine and venous irritation: optimal parenteral administration. J Oncol Pharm Pract. 2005; 11: 79-81.

24. Matsusue S, Nishimura S, Koizumi S, Nakamura T, Takeda H. Preventive effect of simultaneously infused lipid emulsion against thrombophlebitis during postoperative peripheral parenteral nutrition. Surg Today. 1995; 25: 667-71. 